\title{
Aydın Yöresindeki Örtüaltı İşletmelerinin Üretim Sistemleri Açısından İrdelenmesi
}

\author{
Gülsüm ŞIMŞEK ${ }^{1}$ (D) , Necdet DAĞDELEN ${ }^{*}$ (D) \\ ${ }^{1}$ T.C. Recep Tayyip Erdoğan Üniversitesi Teknik Bilimler Meslek Yüksekokulu, Rize \\ ${ }^{2}$ Aydın Adnan Menderes Üniversitesi Ziraat Fakültesi Biyosistem Mühendisliği Bölümü Koçarlı, Aydın
}

Öz: Ülkemizde örtüaltı faaliyetleri ekolojik koşulların etkisiyle gelişmiş olup, özellikle iklimin uygun olduğu başta Akdeniz sahil kesiminde olmak üzere Ege Bölgesi'nde de yaygınlaşmıştır. Ege Bölgesi'nde yer alan Aydın ilinde, Aydın il Tarım ve Orman Müdürlüğü tarafından belirlenen örtüaltı yetiştiricilikle uğraşan 45 adet çiftçiye anket uygulanarak, ölçüm çalışmaları yapılmıştır. Ankette bölge çiftçilerinin eğitim durumu, örtüaltı yetiştiriciliğinde kullanılan üretim sistemi belirlenmiştir. Örtüaltı yapılarında karşılaşılan yaygın sorunlar tespit edilmiştir. Örtüaltı işletmelerinin son yıllardaki gelişme ve değişimlerinin Aydın yöresindeki geleneksel örtüaltı üretimine yansıyıp yansımadığı ve buna yönelik olarak son yıllarda örtüaltı üretim yapılarının mevcut durumu değerlendirilmiştir. Çalışma sonucunda, araştırma alanındaki işletmelerin \% 40'ının ana gelir kaynağının örtüaltı yetiştiriciliği olduğu, \%48.9'unun da ek gelir kaynağı olarak örtü altı yetiştiriciliği yaptı̆̆ı belirlenmiştir. Yöredeki örtüaltı işletme sahiplerinin \%62.2'sinin öz sermayeyi, \%33.4'ünün banka kredisini, \%2.2'sinin devlet

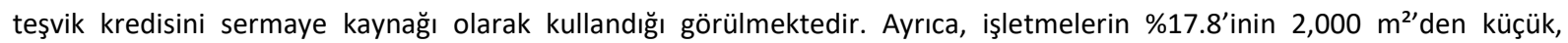
$\% 57.8^{\prime}$ inin 2,000-10,000 $\mathrm{m}^{2}$ arasında, \%24.4'ünün 10,000 $\mathrm{m}^{2}$ 'den büyük arazi alanına sahip olduğu saptanmıştır.

Anahtar Kelimeler: örtüaltı üretim, örtüaltı yapıları, anket, Aydın

\section{Examine of Undercover Systems in Terms of Production Criteria in Aydın Region}

Abstract: Undercovered activities in our country have been developed due to ecological conditions, and have become widespread in the Aegean Region, especially in the Mediterranean coast, where the climate is favorable. In the province of Aydin in the Aegean Region, 45 farmers engaged in undercover farming determined by the Aydin Provincial Directorate of Agriculture and Forestry was surveyed. In the survey, the educational status of the farmers in the region and the structural system used in the cultivation of undergrowth were determined. Common problems encountered in undercovered structures have been identified. It has been evaluated whether the recent developments and changes of undercover enterprises are reflected in the traditional undergone production in Aydin region and the current situation of undercover structures in recent years has been evaluated. As a result of the study, it has been determined that $40 \%$ of the enterprises in the research area are the undercover farming of the main source of income and 48.9\% of the undercover farming as an additional source of income. It can be seen that $62.2 \%$ of the enterprises in the region use equity capital, $33.4 \%$ use bank loan, $2.2 \%$ use government incentive loan as capital resources. In addition, it has been determined that $17.8 \%$ of the enterprises have a land area of less than 2,000 $\mathrm{m}^{2}, 57.8 \%$ between 2,000-10,000 $\mathrm{m}^{2}$, and $24.4 \%$ have a greater than $10,000 \mathrm{~m}^{2}$.

Keywords: undercover production, undercover structures, survey, Aydın

\section{GiRiş}

Dünyada ve Türkiye'de nüfusun günden güne artması sonucu, beslenme, barınma, temiz su kaynakları gibi doğal kaynaklara ve özellikle de tarımsal kaynaklara olan ihtiyaç her geçen gün artmaktadır. Artan nüfusa bağı olarak gıda gereksiniminin karşılanabilmesi için tarımsal üretimde verimliliği artırmak gerekir. Bununla birlikte, dünya genelinde tarımsal kaynakların dengesiz dağılımı, aşırı tüketim, yanlış tarım politikaları, tarımsal kaynaklar açısından daha ciddi sorunlara zemin hazırlamıştır (Şahin ve Kendirli, 2012). Son yıllarda etkisinin giderek daha da arttığı küresel ısınmayla birlikte oluşan iklim değişikliklerinin de göz önüne alınması sonucunda iklime bağlı olmadan ekolojik koşulların kısmen veya tamamen kontrol altına alınarak gerçekleştirildiği örtüaltı yetiştiriciliğinin bu sorunu çözmedeki önemi daha iyi anlaşılmaktadır (Yaslıoğlu ve Durmuş, 2017).

Ülkemizde modern seraların kurulması ve topraksız tarım uygulamaları 1990'ı yıllarda yüksek teknolojinin gelişmesiyle başlamıştır. Seralarda danışmanlı/sertifikalı üretimin ve sürdürülebilir üretim tekniklerinin uygulanmaya başlanması 2000'li yıllarda görülmektedir (Tüzel ve ark., 2008).

Ülkemizde örtüaltı işletmeleri, teknoloji kullanımları, yapısal özellikleri ve büyüklükleri dikkate alındığında ikiye ayrılır. Birincisi küçük ölçekli aile tipi işletmelerdir. Bu işletmelerde teknoloji kullanımı sınırlı olup, üretim genellikle sadece don zararından korumaya yönelik önlemlerin alınmasıyla basit yapılarda gerçekleştirilmektedir. İkincisi ise geleneksel örtüaltı işletmelerinin yanında, son yıllarda büyük kapalı alanlara (10 da ve fazlası) sahip, iklim kontrolünün yapıldığı, topraksız tarım tekniklerinin uygulandığı, ziraat mühendisi ve teknisyenlerin kalıcı kadroyla istihdam edildiği modern

Sorumlu Yazar: ndagdelen@adu.edu.tr. Bu çalışma yüksek lisans tez ürünüdür ve Aydın Adnan Menderes Üniversitesi Bilimsel Araştırma Projeleri (BAP) birimi tarafından desteklenmiştir (Proje No:ZRF-17003).

Geliş Tarihi: 10 Şubat 2020

Kabul Tarihi: 1 Mayıs 2020 
işletmeler olup günden güne yaygınlaşmaya başlamıştır (Tüzel ve ark., 2005). Günümüzde ise tarım alanlarının arttırılmaması ve amacının dışında kullanılmasıyla birim alandan alınan ürün miktarı ve kalitesinin yeterli olmaması sebebiyle tarımsal üretimde karlılık giderek azalarak zirai açıdan kendi kendine yetebilecek bir ülke olan Türkiye, çoğu temel üründe dışa bağımlı bir hale gelmiştir. Bu nedenle birim alandan alınan ürün miktarını ve karlılığı artıran uygulamaların önemi her geçen gün daha da artmaktadır. Bu açıdan iklim koşullarının kontrol altına alınarak yıl boyunca üretimin yapılabileceği örtüaltı üretim tekniklerini geliştirerek, karlılığı ve kaliteyi artıran uygulamalar yapılmalıdır (Şahin ve Kendirli, 2012). Günümüzde ülkemizde tarım alanlarının genişletilmesi mümkün olmadığından birim alandan daha fazla ürün alınabilmesi için, sertifikalı tohum kullanılması gerekir veya halihazırda bulunan tarım alanlarındaki üretimin sürekliliği sağlanmalıdır. Bitkisel üretim için gerekli olan gelişim etmenlerini tüm yıl boyunca sağlayabilen, içinde hareket edilebilir yapı elemanları olarak tanımlanan örtüaltı yapılar, bu sürekliliği sağlamak için daha yaygın kullanılmalıdır (Üstün ve Baytorun, 2003). Bu konuda yapılacak çalışmaların arttırılması ve desteklenmesi ile ülke ekonomisine büyük katkı sağlanacaktır (Şahin ve Kendirli, 2012).

Günümüzde uluslararası seracılığa bakacak olursak, seraların dünya üzerinde geniş bir yayılma alanı olduğunu görürüz. Serin iklim kuşağında yer alan başlıca Avrupa ülkelerinden Hollanda, İngiltere, Danimarka, Almanya, Romanya, Bulgaristan ve Rusya seracılıkta öne çıkmaktadır. Hollanda bu ülkeler içinde 10.000 ha cam sera alanı ve üretim tekniği yönünden en başta gelen ülkedir. Ilıman iklim kuşağındaki yer alan ülkelerin elverişli ekolojik koşulları, seracılığın kârlı olarak yapılmasına olanak sağlamaktadır. Ortalama sıcaklıkların özellikle kış aylarında yüksek olması, seralarda en büyük girdi olan ısıtma masraflarını azaltması nedeniyle, bu ülkelerde sera alanları hızla artmaktadır. Bu iklim kuşağında Akdeniz'e kıyısı bulunan İspanya, Türkiye, İtalya, Yunanistan ve İsrail yer almakta ve bunların içersinde ülkemizin sera kurmaya uygun çok büyük bir potansiyeli bulunmaktadır. İki iklimin egemen olduğu ülkelerde, ortak olan özellik cam ve plastik seraların bir arada oluşudur. Akdeniz ülkelerinde seralarda bu özellikte olmasına karşılık, $A B D$ ve Japonya'da plastik seralarda da yüksek teknoloji uygulanmaktadır (Anonim, 2015).

Türkiye'de 1995 yılında 363.042 dekar alanda seracılık yapılırken 2017 yılında 752.168 dekara çıkarak ikiye katlanmıştır. Söz konusu yaklaşık toplam alanın 85.749 dekarı cam, 355.121 dekarı plastik, 119.899 dekarı yüksek tünel ve 191.399 dekarı alçak tünel seralardır. Türkiye'de örtüaltı üretimin \% 82'si Akdeniz sahil kesiminde, \% 10'u
Ege bölgesinde ve \% 8'i diğer bölgelerimizde yapılmaktadır. Akdeniz sahilindeki örtüaltı işletmelerin \% 40'ı Antalya, \% 22'ü Mersin, \% 15'i Adana, \% 5'i Muğla ilinde bulunmaktadır. Ege Bölgesi'ndeki örtüaltı işletmelerin ise \% 5'i İzmir ilinde ve \% 5'i Aydın'da bulunmaktadır (Anonim, 2015; Anonim, 2017; Büyüktaş ve ark., 2016).

Büyük Menderes Havzası üzerinde bulunan ve 8007 km²lik bir yüzölçümüne sahip olan Aydın ilinin kuzeyinde Aydın Dağları, güneyinde Menteşe dağları bulunmakta, orta ve batı kesimlerini verimli ovalar oluşturmaktadır. $37^{\circ}-44^{\prime}$ ve $38^{\circ}-08^{\prime}$ kuzey enlemleri ile $27^{\circ}-23^{\prime}$ ve $28^{\circ}-52^{\prime}$ doğu boylamları arasında yer alan ilin, kuzeyinde İzmir ve Manisa illeri, güneyinde Muğla ve doğusunda ise Denizli ili bulunmaktadır (Anonim, 2018).

İklim ve bitki örtüsü açısından bakıldığında Akdeniz ikliminin hâkim olduğu ill'de yazlar sıcak ve kurak, kışları ılık ve yağışlı geçer. Ege Bölgesinde bulunan diğer ovalarda olduğu gibi batıda denize doğru açılan bir oluk şeklinde olan Büyük Menderes Ovası'nda, yağış getiren rüzgarlar ile denizin ılıman etkisi iç kesimlere kadar kolaylıkla ulaşır. Ancak Kuzey rüzgarları ovanın Akdeniz Bölgesine oranla daha serin olmasına neden olmaktadır. Aydın iline ait uzun yıllar gözlem sonuçları dikkate alındığında, yıllık toplam yağış değerinin $657.7 \mathrm{~mm}$, ortalama sıcaklık değerinin $17.7^{\circ} \mathrm{C}$, ortalama yıllık oransal nem miktarının $\% 63$ ve yıllık ortalama rüzgar hızı değerinin ise $1.6 \mathrm{~m} / \mathrm{s}$ olduğu belirlenmiştir (Anonim, 2016).

Tarım ve turizm kenti olarak bilinen Aydın ilinde, ekonomik hayatın temelini tarım sektörü oluşturmakla birlikte, sanayi ve ticaret de eknomik faaliyetler içerisinde yoğun olarak yer almaktadır. Tarımın il ekonomisine katkısı \%55 civarındadır. Ülke tarımında önemli bir yere sahip olan il, Türkiye'de üretilen bitkisel ürünlerin 29'unda ilk 10' da yer edinmiştir. Aydın ilinde en çok üretimi yapılan bitkisel ürünler; incir, zeytin, pamuk ve kestanedir. Türkiye üretimine katkısı açısından bakıldığında ilde üretilen ürünlerden incir, kestane, zeytin, kereviz (sap) ve tiritikale (yeşil ot) ülke üretiminde 1. sırada; enginar, pamuk ve çilekte 2. sırada; yer fıstığı ve mandalina (king) üretiminde ise 3. sırada yer almaktadır (Anonim, 2018).

İlin toplam yüzey alanının 368,336 ha'ında (\%47) tarım yapılmaktadır. Sulaması Büyük Menderes Irmağından yapılan tarım alanlarına bakıldığında toprak, iklim, topoğrafya ve ekolojik özellikleri bakımından polikültür tarıma elverişlidir. Toplam tarım alanının \%59'unda $(216,657$ ha) meyve, içecek ve baharat bitkileri yetiştirilmekte; kalan alanların 25,242 ha'ını çayır-mera; 14,950 ha'ını göl-bataklık; 78,540 ha'lık kısmını ise tarım dışı araziler oluşturmaktadır. Tarım yapılan alanların 214,151 ha'lık kısmı sulanabilir araziler oluşturmaktadır (DSi 144,865 
ha; Toprak ve Su Kooperatifleri 2,436 ha; Halk Sulamaları 60,771 ha ve diğer sulamalar 6,079 ha) (Anonim, 2018).

Bu çalışma, Aydın İ Tarım ve Orman Müdürlüğü tarafından belirlenen Aydın yöresinde örtüaltı tarım yapan, 45 adet işletmenin seçilip, üretim sistemlerinin incelenmesi neticesinde örtüaltı işletmelerinin son yıllardaki gelişme ve değişimlerinin Aydın yöresindeki geleneksel sera üretimine yansıyıp yansımadığını belirlemek amacıyla yürütülmüştür. $\mathrm{Bu}$ kapsamda seçilen örtüaltı işletmelerin genel özellikleri, çiftçilere anket uygulanarak belirlenmiş ve ilgili literatür ışığında değerlendirilmiştir.

\section{MATERYAL VE YÖNTEM}

Bu çalışma, Aydın ili yöresindeki örtüaltı yetiştiriciliği yapan işletmeler arasından işletme büyüklükleri ve ulaşım olanakları dikkate alınarak "Gayeli Örnekleme" yöntemiyle seçilen 45 adet işletmede yürütülmüştür (Çiçek ve Erkan 1996). Çalışmada, seçilen işletmelerin üretim sistemleri ve yapıların teknik özellikleri çiftçilerle anket yapılarak belirlenmiştir. Araştırma alanındaki örtüaltı işletmeler, Aydın II Tarım ve Orman Müdürlüğü’nün ilgili kayıtlarına göre tespit edilmiş ve bunların dağılımı Çizelge 1'de gösterilmiştir (Anonim, 2018).
ŞIMŞEK G, DAĞDELEN N Araştırma alanlarında incelenen 45 örtüaltı işletmesinde işletme sahiplerinin özellikleri (eğitim düzeyi, meslek ve deneyim), işletme sahiplerinin örtüaltı yetiştiriciliğine karar vermesinde etkili faktörler, işletmelerde örtüaltı yetiştiriciliğinin ekonomik olarak yeri ve önemi, işletme sahiplerinin örtüaltı üretim sistemlerinin tesisinde yararlandıkları kaynaklar, işletmelerin tipleri, işletmelerin örtüaltı yetiştiricilik olanakları (arazi varlığı, örtüaltı yetiştiricilik alan büyüklüğü), işletmelerde örtüaltı üretim özellikleri (üretim türü, üretim teknikleri, üretim şekli), işletme sahiplerinin gelecekle ilgili eğilimleri, işletmelerin örtüaltı üretim sistemlerinde sorunların çözümünde kurum ve kuruluşlarla iletişimi hakkında bilgiler edinilmiştir. Yöneltilen anket formları ile üreticilere doğrudan görüşme yoluyla sorular sorularak; üreticiler (eğitim durumu, sera varlığı, seracılık yaptığı süre vb.), yetiştiricilik şekillerine (topraklı-topraksız tarım, yetiştiriciliği yapılan tür, üretim şekli, ekim-dikim tarihleri vb.) ilişkin bilgiler toplanmıştır. Anket çalışmaları sonucunda incelenen 45 işletmenin arazi çalışmaları ile elde edilen verileri Microsoft Excel programıyla çizelgeler halinde hazırlanmıştır.

Çizelge 1. Aydın yöresindeki araştırma alanında incelenen örtüaltı işletmelerin ilçelere göre dağılımı

\begin{tabular}{|c|c|c|c|c|c|c|c|c|}
\hline \multirow[t]{2}{*}{ Araştırmanın yapıldığı ilçeler } & \multicolumn{2}{|c|}{$\begin{array}{l}\text { Yüksek tünel sahibi } \\
\text { örtüaltı işletmeler }\end{array}$} & \multicolumn{2}{|c|}{$\begin{array}{l}\text { Alçak tünel sahibi } \\
\text { örtüaltı işletmeler }\end{array}$} & \multicolumn{2}{|c|}{ Sera işletmeleri } & \multicolumn{2}{|c|}{ Toplam } \\
\hline & Adet & $\begin{array}{l}\text { Alan } \\
\left(\mathrm{m}^{2}\right)\end{array}$ & Adet & $\begin{array}{l}\text { Alan } \\
\left(\mathrm{m}^{2}\right)\end{array}$ & Adet & $\begin{array}{l}\text { Alan } \\
\left(\mathrm{m}^{2}\right)\end{array}$ & Adet & $\begin{array}{l}\text { Alan } \\
\left(\mathrm{m}^{2}\right)\end{array}$ \\
\hline Merkez & 15 & 26,800 & - & - & - & - & 15 & 26,800 \\
\hline İncirliova & 19 & 98,950 & - & - & - & - & 19 & 98,950 \\
\hline Germencik & 9 & 70,900 & - & - & 1 & 27,800 & 10 & 98,700 \\
\hline Köşk & - & - & - & - & 1 & 41,400 & 1 & 41,400 \\
\hline Toplam & 43 & 196,650 & - & - & 2 & 69,200 & 45 & 265,850 \\
\hline
\end{tabular}

\section{BULGULAR VE TARTIŞMA}

Araştırma alanındaki örtüaltı işletmelerin sahipleri eğitim düzeyi yönünden ele alındığında; işletme sahiplerinin \%62.2'inin ilköğretim (\%55.5 ilkokul ve \%6.7 ortaokul) mezunu iken, \%17.8'i lise ve \%20'si üniversite mezunu olduğu belirlenmiştir. Üniversite mezun oranların oranı, araştırılan yörenin genelinde düşük, ancak Köşk (\%100) ve Germencik (\%40) ilçelerindeki oran diğer ilçelerle karşılaştırıldığında oldukça yüksektir. Eltez ve Eltez (2005) tarafından İzmir ilinin Bergama ve Dikili ilçelerinde yaptıkları bir araştırma sonucunda, örtüaltı işletme sahipleri eğitim düzeyleri açısından ele alındığında \%60'ının ilköğretim, \%10'unun lise ve \%30'unun ise üniversite mezunu olduğu saptanmıştır. Türkay ve ark. (2006) tarafından Mersin ilinin Anamur ilçesinde yapılan bir araştırma sonucunda, örtüaltı işletme sahiplerinin \%48'inin ilkokul, \%18'inin ortaokul, \%14'ünün lise ve \%20'sinin üniversite mezunu olduğu tespit edilmiştir. İzmir ilinin Menderes ilçesinde yapılan bir araştırmaya göre, örtüaltı işletme sahiplerinin \%77.23'ünün ilkokul, \%8.91'inin ortaokul, \%10.89'unun lise, \%2.97'sinin ise üniversite mezunu olduğu belirlenmiştir (Gökçimen, 2009). Tüzel ve ark., (2010) tarafından Antalya ilinin Serik ilçesinde yapılan benzer başka bir araştırmada ise, geleneksel örtüaltı işletme sahiplerinin \%90'ının ilkokul, $\% 10$ 'unun lise mezunu olduğu ve modern örtüaltı işletmelerinde de $\% 25^{\prime}$ inin lise, $\% 75^{\prime}$ inin ise üniversite mezunu olduğu saptanmıştır. İşbecer (2010) tarafından Antalya iline ait Demre, Kumluca, Finike, Kepez, Aksu, Serik, Manavgat, Alanya ve Gazipaşa ilçelerinde yapılan bir araştırmaya göre, örtüaltı işletme sahiplerinin \%66.1'inin ilkokul, \%20.6'sının ortaokul, \%11.7'sinin lise, \%1.7'sinin ise üniversite mezunu olduğu tespit edilmiştir. Manisa yöresinde yapılan bir başka araştırmada ise, örtüaltı işletme sahiplerinin \%70'inin ilkokul, \%10'unun ortaokul, \%5'inin lise ve \%15'inin üniversite mezunu olduğu tespit edilmiştir (Mercan, 2013). Bu sonuçlara bakıldığında, Aydın yöresindeki örtüaltı üretim yapan işletme sahiplerinin eğitim seviyelerinin, Bergama ve Dikili, Anamur yörelerine göre düşük olmasına rağmen, Serik, Antalya, Menderes ve Manisa yörelerine göre yüksek olduğu anlaşılmaktadır. 
Sonuç olarak örtüaltı işletmelerde, geleneksel işletmecilikten modern işletmeciliğe geçmiş olan yörelerde, eğitim düzeyinin daha yüksek olduğu görülmektedir.

Yöredeki örtüaltı işletmelerin sahipleri meslek yönünden ele alındığında; \%68.9'unun çiftçi iken, sadece \%6.7'sinin ziraat mühendisi ve \%24.4'ünün ise diğer mesleklerden olduğu belirlenmiştir (Çizelge 2). Örtüaltı işletmeciliği yapan işletme sahiplerinin çoğunluğunun mesleki eğitim düzeylerinin düşük olduğu anlaşılmaktadır.

Araştırma alanındaki işletmelerin sahipleri örtüaltı yetiştiricilik deneyimi açısından ele alındığında, işletmelerin \%17.8'inin 5 yıldan az, \%13.3'ünün 5-10 yıl arasında, $\% 22.2$ 'sinin 10-20 yıl arasında ve \%46.7'sinin 20 yıldan fazla bir deneyime sahip olduğu görülmüştür. Eltez ve Eltez (2005) tarafından İzmir ilinin Bergama ve Dikili ilçelerinde yaptıkları bir araştırma sonucunda, örtüaltı sahiplerinin $\% 69$ 'unun 5 yıl ve 5 yıldan daha az, \%8'inin 6-8 yıl arasında, \%23'ünün 9 ve 9 yıldan daha fazla deneyime sahip olduğu saptanmıştır. Çanakçı ve Akıncı (2007), tarafından Antalya yöresinde yapılan anket çalışması sonucunda, örtüaltı işletme sahiplerinin deneyim sürelerinin 3-37 yıl arasında değiştiğini ve ortalama deneyim sürelerinin yaklaşık 19 yıl olduğunu belirlemişlerdir. Antalya'nın Kumluca İlçesinde yapılan çalışmada örtüaltı işletme sahiplerinin deneyim süreleri incelendiğinde \%34'ünün 17 yıldan daha uzun bir zamandan bu yana deneyime sahip olduğu görülmüş, \%13.3'ünün 5 yıldan az, \%52.7'sinin 5-17 yıl arasında olduğunu tespit etmişlerdir ve bu çalışmaların sonucunda örtüaltı yetiştiricilik deneyim sürelerinin ortalama 15-20 yıl arasında değiştiği saptanmıştır (Yalçın ve Boz, 2007). Türkay ve ark. (2006) tarafından Mersin ilinin Anamur ilçesinde yapılan bir araştırma sonucunda örtüaltı işletmelerin \%9'unun 1980-1989, \%24'ünün 1990-1999 yılları arasında ve \%67'sinin ise 2000 yılından sonra inşa edildiği belirlenmiştir. İzmir ilinin Menderes ilçesinde yapılan bir başka araştırmada ise örtüaltı üretim işletmelerinin \%7.14'ünün 1985-1990, \%21.42'sinin 1990-1995, \%58.35'inin 1995-2000, \%10.7'sinin 2000-2005 ve \%2.38'inin 2005-2008 yılları arasında inşa edildiği tespit edilmiştir (Gökçimen, 2009). Antalya ilinde yapılan araştırmada örtüaltı üreticilerin \%31.1'inin 15-20, \%26.1'inin 9-14 ve \%17.2'sinin ise 27 yıldan fazla örtüaltı yetiştiricilikle uğraştığı saptanmıştır (İşbecer, 2010). Mercan (2013) tarafından Manisa yöresinde incelenen işletmelerde, işletme sahiplerinin örtüaltı yetiştiricilik deneyimleri ele alındığında, işletmelerin \%40'ının 5 yıldan az, \%42.5'inin 510 yıl arasında ve \%17.5'inin 10 yıldan fazla olduğu belirlenmiştir. Buradan sonuçla, Aydın yöresindeki işletme sahiplerinin deneyimi, Antalya, Kumluca, Menderes yörelerine göre düşük, Bergama, Dikili, ve Anamur yöresine göre yüksek olduğu saptanmıştır.

Aydın yöresinde araştırma alanındaki işletme sahiplerinin örtüaltı yetiştiriciliğine karar verme yönünden değerlendirildiğinde, seçilen işletmelerin \%35.6'sı bulunduğu yöredeki, \%11.1'i diğer yörelerdeki işletme sahiplerinin görüş ve önerileri, \%22.2'si baba mesleği olduğu için, \%6.7 si kamu kurum ve kuruluşlarındaki uzman kişilerin görüş ve önerileri, \%4.4'ü bulunduğu yöredeki tarım ilacı, tohum, fide pazarlayıcılarının görüş ve önerileri, \%6.7'si hem bulunduğu yörenin hem de diğer yörelerdeki işletme sahiplerinin görüş ve önerileri, \%13.3'ü ise hem baba mesleği olması hem de yöredeki uzman kişilerin görüş ve önerileri etkili olmuştur. Sonuç olarak, örtüaltı yetiştiriciliğinin yaygınlaşmasında daha çok bulunduğu yöredeki işletme sahiplerinin faaliyetleri, görüş ve önerilerinin etkili olmasının yanı sıra eğer kişi çiftçiyse genellikle onun çocuklarının da çiftçi olmasına etkili olduğu görülmektedir.

Araştırma alanındaki işletmelerin örtüaltı yetiştiriciliğini ekonomik olarak yapma nedenleri incelendiğinde, örtüaltı işletmelerin \%40'ının ana gelir kaynağı, \%48.9'unun ek gelir kaynağı ve \%11.1'inin ise deneme amaçlı olduğu belirlenmiştir (Çizelge 3). Bu durum değerlendirildiğinde, Aydın yöresindeki örtüaltı işletmelerin ekonomik açıdan önemli bir yerinin olduğu anlaşılmaktadır.

Yöredeki örtüaltı işletme sahiplerinin üretim sistemlerini kurarken faydalandıkları sermaye kaynakları incelendiğinde, \%62.2'sinin öz sermayeyi, \%33.4'ünün banka kredisini, \%2.2'sinin devlet teşvik kredisini kullandığı görülmektedir. Birlikte yararlanılan kaynaklar ele alındığında, \%2.2'sinin öz sermaye ile banka kredisini birlikte kullandığı anlaşılmıştır (Çizelge 4).

İzmir'in Menderes ilçesinde yapılan bir araştırmaya göre, örtüaltı yetiştiriciliği yapan üretim sistemleri tesisinde,

Çizelge 2. İşletme sahiplerinin meslekleri

\begin{tabular}{llllllll}
\hline \multirow{2}{*}{ Araştırma Alanı } & Meslek & \multicolumn{2}{l}{ Ziraat Mühendisi } & \multicolumn{2}{c}{ Çiftçi } & \multicolumn{2}{c}{ Diğer } \\
\cline { 2 - 7 } & İşletme Sayısı & Sayı & \% & Sayı & \% & Sayı & \% \\
\hline Merkez & 15 & - & - & 13 & 86.7 & 2 & 13.3 \\
Incirliova & 19 & 1 & 5.3 & 13 & 68.4 & 5 & 26.3 \\
Germencik & 10 & 2 & 20 & 5 & 50 & 3 & 30 \\
Köşk & 1 & - & - & - & - & 1 & 100 \\
TOPLAM & 45 & 3 & 6.7 & 31 & 68.9 & 11 & 24.4 \\
\hline
\end{tabular}


Çizelge 3. İşletme sahiplerinin örtüaltı yetiştiriciliğini ekonomik olarak yapma nedenleri

\begin{tabular}{|c|c|c|c|c|c|c|c|}
\hline \multirow[t]{2}{*}{ Araştırma Alanı } & \multirow[t]{2}{*}{$\begin{array}{l}\text { İşletme } \\
\text { Sayısı }\end{array}$} & \multirow{2}{*}{$\begin{array}{l}\text { Ana } \\
\text { Olarak } \\
\text { Sayı }\end{array}$} & Gelir & \multicolumn{2}{|c|}{$\begin{array}{l}\text { Diğer Üretim Faaliyetlerine (Bitkisel } \\
\text { ya da hayvansal) Ek Olarak }\end{array}$} & \multicolumn{2}{|c|}{$\begin{array}{ll}\text { Alternatif } & \text { Geçim } \\
\text { Kaynağı } & \text { Olarak } \\
\text { Deneme Amaçlı } & \\
\end{array}$} \\
\hline & & & $\%$ & Sayı & $\%$ & Sayı & $\%$ \\
\hline Merkez & 15 & 6 & 40 & 8 & 53.3 & 1 & 6.7 \\
\hline İncirliova & 19 & 8 & 42.1 & 10 & 52.6 & 1 & 5.3 \\
\hline Germencik & 10 & 4 & 40 & 4 & 40 & 2 & 20 \\
\hline Köşk & 1 & - & - & - & - & 1 & 100 \\
\hline TOPLAM & 45 & 18 & 40 & 22 & 48.9 & 5 & 11.1 \\
\hline
\end{tabular}

Çizelge 4. İşletme sahiplerinin örtüaltı üretim sistemleri tesisini kurarken faydalandıkları sermaye kaynakları

\begin{tabular}{|c|c|c|c|c|c|c|c|c|c|}
\hline \multirow{3}{*}{ Araştırma Alanı } & \multirow{3}{*}{ İşletme Sayısı } & \multicolumn{2}{|c|}{$\begin{array}{l}\text { Öz Sermaye } \\
\text { (1) }\end{array}$} & \multicolumn{2}{|c|}{$\begin{array}{l}\text { Banka Kredisi } \\
\text { (2) }\end{array}$} & \multirow{3}{*}{$\begin{array}{l}\text { Devlet } \\
\text { Kredisi }\end{array}$} & \multirow{3}{*}{$\begin{array}{l}\text { Teşvik } \\
\%\end{array}$} & \multirow{2}{*}{\multicolumn{2}{|c|}{$\begin{array}{l}\text { Yararlanılan } \\
\text { Kaynaklar } \\
1+2\end{array}$}} \\
\hline & & \multirow{2}{*}{ Sayı } & \multirow{2}{*}{$\%$} & \multirow{2}{*}{ Sayı } & \multirow{2}{*}{$\%$} & & & & \\
\hline & & & & & & & & Sayı & $\%$ \\
\hline Merkez & 15 & 11 & 73.3 & 3 & 20 & 1 & 6.7 & - & - \\
\hline İncirliova & 19 & 13 & 68.4 & 5 & 26.3 & - & - & 1 & 5.3 \\
\hline Germencik & 10 & 3 & 30 & 7 & 70 & - & - & - & - \\
\hline Köşk & 1 & 1 & 100 & - & - & - & - & - & - \\
\hline TOPLAM & 45 & 28 & 62.2 & 15 & 33.4 & 1 & 2.2 & 1 & 2.2 \\
\hline
\end{tabular}

örtüaltı işletme sahiplerinin \%60.72'sinin öz sermayeyi, \%39.28'i ise çeşitli kuruluşlarda aldıkları krediyi kullandığı, kredi kullanan işletme sahiplerinin ise \%93.94'ünün banka kredisi ve \%6.06'sının ise Tarım Kredi Kooperatifi desteği aldığı tespit edilmiştir (Gökçimen 2009). Mercan (2013) tarafından Manisa yöresinde yapılan başka bir araştırmaya göre, yöredeki işletme sahiplerinin \%45'inin öz sermayeyi, \%25'inin Tarım Kredi Kooperatif desteğini ve \%15'inin ise banka kredisini kullandığı saptanmıştır. Bu kaynakların birlikte kullanımı dikkate alındığında ise; işletme sahiplerinin \%10'unun öz sermaye ve banka kredisini, \%2.5'inin öz sermaye ve Tarım Kredi Kooperatif desteğini ve \%2.5'inin ise öz sermaye, banka kredisi ve ihracat desteğini birlikte kullandıkları belirlenmiştir. Bu sonuçlara göre, Aydın yöresindeki işletmelerin örtüaltı üretim tesislerinde öz sermaye kullanımının İzmir'in Menderes ilçesine ve Manisa yöresine göre daha fazla olduğu, diğer bir ifadeyle İzmir'in Menderes ilçesi ile Manisa yöresindeki işletme sahiplerinin daha çok kredi aldığı ve devlet teşvik kredisinden yeterince yararlanamadıkları anlaşılmaktadır.

Yörede incelenen örtüaltı işletmeleri işletme tipi yönünden ele alındığında; işletmelerin \%68.9'unun aile tipi işletme olduğu, \%31.1'inin ise ticari tip işletme olduğu görülmüştür.
Merkez (\%93.3) ve İncirliova (\%63.2) ilçelerinde aile tipi işletmelerin, Köşk (\%100) ilçesinde ticari tipi işletmelerin daha yoğun olduğu anlaşılmıştır. Germencik (\%50) ilçesinin yarısının aile tip, yarısının ise ticari tip işletme olduğu belirlenmiştir. Mercan (2013) tarafından Manisa yöresinde yapılan benzer bir araştırmaya göre, işletmelerin \%80'inin aile tipi, \%20'sinin ise ticari tip işletme olduğu saptanmıştır. Bu sonuçlara göre, örtüaltı yetiştiriciliğinin Aydın ve Manisa yörelerinde daha çok aile tipi işletmelerce yapıldığı anlaşılmaktadır.

Yöredeki işletmelerin örtüaltı yetiştiriciliğinde toplam tarım alanı büyüklüğü açısından ele alındığında, işletmelerin $\% 17.8^{\prime}$ inin 2,000 $\mathrm{m}^{2 \prime}$ den küçük, \%57.8'inin 2,000-10,000 m² arasında, \%24.4'ünün 10,000 $\mathrm{m}^{2}$ 'den büyük arazi alanına sahip olduğu saptanmıştır. Köşk (\%100) ilçesindeki işletmelerde $10,000 \mathrm{~m}^{2}$ ' den büyük tarım alanları çoğunlukta iken, Merkez (\%53.3), İncirliova (\%57.9), Germencik (\%70) ilçelerinde ise 2,000-10,000 $\mathrm{m}^{2}$ arasında tarım alanlarına sahip işletmelerin çoğunlukta olduğu görülmüştür (Çizelge 5). Bu sonuçlara bakıldığında, incelenen işletmelerin önemli bir bölümünde tarım alanı büyüklüğünün 2,000 $\mathrm{m}^{2 \prime}$ den fazla olduğu anlaşılmaktadır.

Çizelge 5. Aydın yöresindeki işletmelerin örtüaltı yetiştiriciliğinde arazi olanakları

\begin{tabular}{|c|c|c|c|c|c|c|c|c|c|c|c|c|c|c|}
\hline \multirow{4}{*}{$\begin{array}{l}\text { Araştırma } \\
\text { Alanı }\end{array}$} & \multicolumn{14}{|c|}{ Arazi Varlığı } \\
\hline & \multirow{3}{*}{$\begin{array}{l}\text { İşletme } \\
\text { Sayısı }\end{array}$} & \multicolumn{6}{|c|}{ Toplam Tarım Alanı Büyüklüğü $\left(\mathrm{m}^{2}\right)$} & \multirow{3}{*}{$\begin{array}{l}\text { İşletme } \\
\text { Sayısı }\end{array}$} & \multicolumn{6}{|c|}{ Örtüaltı Yetiştiricilik Alanı Büyüklüğü $\left(\mathrm{m}^{2}\right)$} \\
\hline & & \multicolumn{2}{|c|}{$<2000$} & \multicolumn{2}{|c|}{$2000-10000$} & \multicolumn{2}{|c|}{$10000<$} & & \multicolumn{2}{|c|}{$<2000$} & \multicolumn{2}{|c|}{$2000-10000$} & \multicolumn{2}{|c|}{$10000<$} \\
\hline & & Sayı & $\%$ & Sayı & $\%$ & Sayı & $\%$ & & Sayı & $\%$ & Sayı & $\%$ & Sayı & $\%$ \\
\hline Merkez & 15 & 7 & 46.7 & 8 & 53.3 & - & - & 15 & 9 & 60 & 6 & 40 & - & - \\
\hline İncirliova & 19 & 1 & 5.3 & 11 & 57.9 & 7 & 36.8 & 19 & 3 & 15.8 & 14 & 73.7 & 2 & 10.5 \\
\hline Germencik & 10 & - & - & 7 & 70 & 3 & 30 & 10 & - & - & 7 & 70 & 3 & 30 \\
\hline Köşk & 1 & - & - & - & - & 1 & 100 & 1 & - & - & - & - & 1 & 100 \\
\hline TOPLAM & 45 & 8 & 17.8 & 26 & 57.8 & 11 & 24.4 & 45 & 12 & 26.7 & 27 & 60 & 6 & 13.3 \\
\hline
\end{tabular}


Yörede incelenen işletmelerin örtüaltı yetiştiricilik alanı yönünden ele alındığında, örtüaltı alanları işletmelerin \%26.7'sinde 2,000 $\mathrm{m}^{2 \prime}$ den az, \%60'ında 2,000-10,000 $\mathrm{m}^{2}$ arasında ve \%13.3'ünde ise $10,000 \mathrm{~m}^{2 \prime}$ den fazla olduğu saptanmıştır. Yöredeki örtüaltı yetiştiricilik alanı Merkez ilçelerindeki işletmelerin \%60'ında 2,000 $\mathrm{m}^{2 \prime}$ den az, Germencik ilçesindeki işletmelerin $\% 70$ ve İncirliova ilçesindeki işletmelerin \%73.3'ünde 2,000-10,000 $\mathrm{m}^{2}$ arasında, Köşk ilçesindeki işletmelerde tamamının 10,000 $\mathrm{m}^{2 \prime}$ den fazla olduğu belirlenmiştir (Çizelge 5). Eltez ve Eltez (2005) tarafından İzmir'in Bergama ve Dikili ilçelerinde yapılan bir araştırmaya göre, örtüaltı yetiştiricilik alanı işletmelerinin \%23'ünün $10,000 \mathrm{~m}^{2 \prime}$ den fazla, \%77'sinin ise $10,000 \mathrm{~m}^{2}$ 'den az olduğu görülmüştür. Emekli ve ark. (2007) tarafından Antalya ilinin Kumluca ilçesinde yapılan bir araştırmada ise, örtüaltı üretim alanının işletmelerin $\% 15.7$ 'sinde 4,500 $\mathrm{m}^{2 \prime}$ den büyük, \%84.3'ünün 4,500 $\mathrm{m}^{2 \prime}$ den küçük olduğu anlaşılmıştır. Gale ve ark. (2014) tarafından Antalya'nın Kepez ilçesinde yürütülen çalışmaya göre, üreticilerin \%93.3'ünün örtüaltı üretim alanının 10,000 $\mathrm{m}^{2 \prime}$ den az, \%6.7'sinin örtüaltı varlığının 10,000 $\mathrm{m}^{2 \prime}$ den fazla olduğu saptanmıştır. Bu sonuçlar değerlendirildiğinde, Aydın yöresindeki işletmelerde örtüaltı yetiştiricilik alanlarının İzmir'in Bergama ve Dikili ilçelerine ve Antalya ilinin Kumluca ilçesindeki işletmelere göre daha az olduğu, Antalya'nın Kepez ilçesindeki işletmelere göre daha fazla olduğu belirlenmiştir.

Yöredeki araştırma alanında incelen işletmelerin işgücü olanakları açısından değerlendirildiğinde, örtüaltı işletmelerin \%33.2'sinde sadece aile bireylerinin çalıştığı, \%6.7'sinde sadece mevsimlik işçilerin çalıştığı, \%8.9'unda sadece daimi işçilerin çalıştığı tespit edilmiştir. Yöredeki farklı işgücü olanaklarının birlikte kullanımına bakıldığında, yörede incelenen örtüaltı işletmelerin \%37.8'inde aile bireyleri ile mevsimlik işçilerin birlikte çalıştığı, \%6.7'sinde aile bireyleri ile daimi işçilerin birlikte çalıştığı, \%6.7'sinde ise mevsimlik işçilerle daimi işçilerin birlikte çalıştığı saptanmıştır. Gökçimen (2009) tarafından İzmir ilinin Menderes ilçesinde yapılan çalışmaya göre, örtüaltı işletmelerin \%2.38'inde aileden hiç kimse çalışmayıp dışarıdan işgücüne başvurarak yetiştiricilik devam etmektedir. Bununla birlikte işletmelerin \%80.95'inde aileden 2-4 kişi çalışmaktadır. Elde edilen sonuçlar
Menderes ilçesindeki örtüaltı işletmelerinde çok fazla dışarıdan işgücü alımına başvurulmadığını ortaya koymuştur.

Araştırma alanında incelenen işletmelerin uyguladıkları örtüaltı üretim türleri ele alındığında, işletmelerin \%93.3'ünde meyve ve sebze yetiştiriciliği ve \%6.7'sinde kesme çiçek yetiştiriciliği yapıldığı anlaşılmıştır (Çizelge 6). Araştırma alanındaki işletmelerin hiç birinde tahıl-hububat ve fide yetiştiriciliği yapılmadığı belirlenmiştir. Taşlıgil ve Şahin (2014), tarafından Marmara Bölgesi'nde yaptıkları araştırmaya göre Marmara Bölgesi'nde sebze ve meyvelerden sonra üçüncü grubu süs bitkilerinin oluşturduğu saptanmıştır. Bu durum değerlendirildiğinde, Aydın yöresinde ve Marmara Bölgesi'ndeki örtüaltı üretim sistemlerinde meyve-sebzeciliğin yaygın olarak yapıldığını ekonomik getirisi daha fazla olmasına rağmen kesme çiçek yetiştiriciliğinin yeteri kadar yapılmadığını göstermektedir. Yöredeki araştırma alanında incelenen işletmeler örtüaltı yetiştiriciliğinde uyguladıkları üretim teknikleri açısından değerlendirildiğinde, örtüaltı işletmelerin \%11.1'inde topraksız tarım, \%88.9'unda topraklı tarım yapıldığı saptanmıştır (Çizelge 6). Köşk ilçesinin tamamında topraksız tarım uygulaması yapılırken, Germencik ilçesinin \%20'sinde, Incirliova ilçesinin ise \%5.3'ünde topraksız tarım uygulanır. Araştırma alanındaki örtüaltı işletmelerinde Merkez ilçelerinin tamamında topraklı tarım uygulanırken, İncirliova ilçesinin \%94.7'sinde, Germencik ilçesinin \%80'ninde topraklı tarım yapılmaktadır. Mercan (2013) tarafından Manisa yöresinde yürütülen araştırma sonucunda örtüaltı işletmelerin \%82.5'inde topraklı tarım, \%17.5'inde topraksız tarım uygulandığı belirlenmiştir. Bu sonuçlara göre, Aydın ve Manisa yöresindeki örtüaltı üretim yapan işletmelerin büyük bir kısmında topraklı tarım tekniğinin uygulandığı tespit edilmiş olup işletmelerin çoğunluğunda modern tarım tekniği yerine geleneksel tarım tekniğinin uygulandığı anlaşılmaktadır.

Aydın yöresinde incelen 45 işletme örtüaltı yetiştiriciliğinde uyguladıkları üretim şekli Çizelge 7'de verilmiştir.

Örtüaltı yetiştiricilik açısından sonuçlar ele alındığında, işletmelerin \%89'unun ilkbahar ve sonbahar yetiştiriciliği yaptığı, \%4.4'ünün sadece ilkbahar yetiştiriciliği, \%4.4'ünün sadece tek ürün yetiştiriciliği, \%2.2'sinin sadece sonbahar yetiştiriciliği yaptığı saptanmıştır. İlkbahar ve sonbahar

Çizelge 6. İşletmelerde örtüaltı üretim türü ve uygulama biçimleri

\begin{tabular}{|c|c|c|c|c|c|c|c|c|c|c|c|c|c|c|}
\hline \multirow{3}{*}{$\begin{array}{l}\text { Araştırma } \\
\text { Alanı }\end{array}$} & \multicolumn{9}{|c|}{ Üretim Türü } & \multicolumn{5}{|c|}{ Üretim Teknikleri } \\
\hline & \multirow{2}{*}{$\begin{array}{l}\text { İşletme } \\
\text { Sayısı }\end{array}$} & \multicolumn{2}{|c|}{$\begin{array}{l}\text { Meyve- } \\
\text { Sebze }\end{array}$} & \multicolumn{2}{|c|}{$\begin{array}{l}\text { Tahıl- } \\
\text { Hububat }\end{array}$} & \multicolumn{2}{|c|}{$\begin{array}{l}\text { Kesme } \\
\text { Çiçek }\end{array}$} & \multicolumn{2}{|l|}{ Fide } & \multirow{2}{*}{$\begin{array}{l}\text { İşletme } \\
\text { Sayısı }\end{array}$} & \multicolumn{2}{|c|}{$\begin{array}{l}\text { Topraklı } \\
\text { Tarım }\end{array}$} & \multicolumn{2}{|c|}{ Topraksız Tarım } \\
\hline & & Sayı & $\%$ & Sayı & $\%$ & Sayı & $\%$ & Sayı & $\%$ & & Sayı & $\%$ & Sayı & $\%$ \\
\hline Merkez & 15 & 14 & 93.3 & - & - & 1 & 6.7 & - & - & 15 & 14 & 93.3 & 1 & 6.7 \\
\hline İncirliova & 19 & 19 & 100 & - & - & - & - & - & - & 19 & 18 & 94.7 & 1 & 5.3 \\
\hline Germencik & 10 & 8 & 80 & - & - & 2 & 20 & - & - & 10 & 8 & 80 & 2 & 20 \\
\hline Köşk & 1 & 1 & 100 & - & - & - & - & - & - & 1 & - & - & 1 & 100 \\
\hline TOPLAM & 45 & 42 & 93.3 & - & - & 3 & 6.7 & - & - & 45 & 40 & 88.9 & 5 & 11.1 \\
\hline
\end{tabular}


Çizelge 7. İşletmelerin örtüaltı yetiştiricilik şekli

\begin{tabular}{|c|c|c|c|c|c|c|c|c|c|}
\hline \multirow{3}{*}{$\begin{array}{l}\text { Araştırma } \\
\text { Alanı }\end{array}$} & \multicolumn{9}{|l|}{ Üretim Şekli } \\
\hline & \multirow{2}{*}{ İşletme Sayısı } & \multicolumn{2}{|c|}{$\begin{array}{l}\text { Illkbahar } \\
\text { Yetiştiriciliği }\end{array}$} & \multicolumn{2}{|c|}{$\begin{array}{l}\text { Sonbahar } \\
\text { Yetiştiriciliği }\end{array}$} & \multicolumn{2}{|c|}{$\begin{array}{l}\text { Illkbahar ve Sonbahar } \\
\text { Yetiştiriciliği }\end{array}$} & \multicolumn{2}{|c|}{ Tek Ürün Yetiştiriciliği } \\
\hline & & Sayı & $\%$ & Sayı & $\%$ & Sayı & $\%$ & Sayı & $\%$ \\
\hline Merkez & 15 & 2 & 13,3 & 1 & 6,7 & 12 & 80 & - & - \\
\hline İncirliova & 19 & - & - & - & - & 19 & 100 & - & - \\
\hline Germencik & 10 & - & - & - & - & 8 & 80 & 2 & 20 \\
\hline Köşk & 1 & - & - & - & - & 1 & 100 & - & - \\
\hline TOPLAM & 45 & 2 & 4,4 & 1 & 2,2 & 40 & 89 & 2 & 4,4 \\
\hline
\end{tabular}

yetiştiriciliğinin Incirliova ve Köşk ilçelerinin tamamında, Merkez ve Germencik ilçelerinin \%80'inde uygulandığı görülmektedir. Çanakçı ve Akıncı (2007) tarafından Antalya ilinde yapılan bir araştırmaya göre ise, örtüaltı işletme sahiplerinin \%41.9'unun ilkbahar ve sonbahar yetiştiriciliği, \%58.1'inin tek ürün yetiştiriciliği yaptığı belirlenmiştir. Güllüler (2007) tarafından Adana yöresinde yaptığı bir araştırmada, örtüaltı işletmelerin \%56.5'inin ilkbahar ve sonbahar yetiştiriciliği, \%43.5'inin tek ürün yetiştiriciliği yaptığı saptanmıştır. Bu sonuçlara bakıldığında, Aydın, Mersin, Adana yörelerindeki örtüaltı işletmelerin çoğunluğunun ilkbahar ve sonbahar yetiştiriciliğini tercih ettiği, Antalya yöresinde ise işletme sahiplerinin büyük bir kısmının tek ürün yetiştiriciliğini tercih ettiği söylenebilir. Bu durum değerlendirildiğinde Aydın ve Adana yörelerinde örtüaltı yetiştiriciliğinin daha çok aile tipi işletme şeklinde yapılmasından kaynaklandığı ifade edilebilir.

Araştırma alanındaki örtüaltı işletmesi sahiplerinin gelecekte işletmeyi büyütme eğilimleri incelendiğinde, yöredeki işletmelerin \%82.2'sinin işletmeyi büyütmeyi düşünmediği, \%17.8'inin işletmeyi büyütmeyi planladığı ortaya çıkmıştır. Aydın yöresindeki örtüaltı işletme sahiplerinin hepsinin, işletmenin büyütülmesiyle ilgili sorun yaşadıkları görülmüştür (Çizelge 8 ).

Aydın yöresindeki örtüaltı işletme sahiplerinin işletmeyi gelecekte büyütmesiyle ilgili karşılaştıkları başlıca sorunlar incelendiğinde, \%55.6'sının kalifiye işgücünün yetersizliğinden, \%28.9'unun sermaye yetersizliğinden, \%15.5'inin ise arazi yetersizliğinden kaynaklandığı anlaşılmaktadır. Bu bağlamda, Aydın yöresindeki örtüaltı işletme sahiplerinin, karşılaştıkları sorunların çözümünde, \%40'ının sorunları kendi içinde çözdüğü, \%60'ının sorunlarını kurum ve kuruluşlardan yardım alarak çözdüğü görülmektedir. İnceleme yapılan yöredeki örtüaltı işletme sahiplerinin karşılaştıkları farklı sorunlara bağlı olarak iletişim kurdukları kurum ve kuruluşlar ele alındığında, \%37.1'inin tesisi kuran ya da malzemenin temin edildiği firmanın, \%33.3'ünün komşu işletme sahiplerinin, \%18.5'inin il Tarım ve Orman Müdürlüğü'nün, \%7.4'ünün Üniversite/Fakülte/MYO'nun, \%3.7'sinin tohum-fide temin edildiği firmaların olduğu tespit edilmiştir (Çizelge 9). Araştırma sonuçları değerlendirildiğinde, Aydın yöresindeki işletme sahiplerinin işletme ile ilgili karşılaştıkları sorunları çözüme kavuşturma konusunda daha çok tesisi kuran ya da malzemenin temin edildiği firmalarla veya komşu işletme sahipleriyle iletişime geçtikleri görülmektedir.

\section{SONUÇ}

Aydın yöresinde seracılığın halen gelenekselliğini koruduğu, çevreye duyarlı üretim tekniklerinin önem kazanmasına ve duyarlılığın artmasına rağmen üreticilerimizin bu konuda yeteri kadar bilgi sahibi olmadığı ve 2-3 dekarın altında üretim alanına sahip olan işletmelerin gelişmelere uyum sağlayamadığı belirlenmiştir. Anket yapılan sera işletmesi sahiplerinin gelecekte işletmelerini büyütülmesini engelleyen faktörler olarak arazi yetersizliği, kalifiye işgücündeki olumsuzluklar, sermaye azlığı ve çiftçiden ucuz alınıp piyasaya pahalı bir şekilde arz edilmesi sonucu kazançlarının emeklerini korumaması şeklinde ifade etmişlerdir. Bunun için devlet teşviklerinin artırılması ve gerekli düzenlemelerin yapılması gerekmektedir. Üreticilerin zirai bilgi eksikliğini giderebilmesi ve doğru tarım tekniklerini uygulayabilmesi için tarım danışmanından destek almalı ya da işletmelerde ziraat mühendisi veya tekniker çalıştırmalıdır. İşletmede yapısal veya üretim

Çizelge 8. İşletme sahiplerinin gelecekle ilgili düşünceleri

\begin{tabular}{|c|c|c|c|c|c|c|c|c|c|c|}
\hline \multirow{3}{*}{$\begin{array}{l}\text { Araştırma } \\
\text { Alanı }\end{array}$} & \multicolumn{5}{|c|}{ Gelecekte İşletmeyi Büyütme Eğilimi } & \multicolumn{5}{|c|}{ İşletmenin Büyütmesiyle İlgili Yaşanan Sorunların Durumu } \\
\hline & \multirow{2}{*}{ İşletme Sayısı } & \multicolumn{2}{|c|}{$\begin{array}{l}\text { Büyütmeyi } \\
\text { Düşünen }\end{array}$} & \multicolumn{2}{|c|}{$\begin{array}{l}\text { Büyütmeyi } \\
\text { Düşünmeyen }\end{array}$} & \multirow{2}{*}{ İşletme Sayısı } & \multicolumn{2}{|c|}{$\begin{array}{l}\text { Sorun } \\
\text { Yaşayan } \\
\text { İşletmeler }\end{array}$} & $\begin{array}{l}\text { Sorun } \\
\text { İşletmeler }\end{array}$ & Yaşamayan \\
\hline & & Sayı & $\%$ & Sayı & $\%$ & & Sayı & $\%$ & Sayı & $\%$ \\
\hline Merkez & 15 & 3 & 20 & 12 & 80 & 15 & 15 & 100 & - & - \\
\hline İncirliova & 19 & 4 & 22.2 & 15 & 77.8 & 19 & 19 & 100 & - & - \\
\hline Germencik & 10 & 1 & 10 & 9 & 90 & 10 & 10 & 100 & - & - \\
\hline Köşk & 1 & - & - & 1 & 100 & 1 & 1 & 100 & - & - \\
\hline TOPLAM & 45 & 8 & 17.8 & 37 & 82.2 & 45 & 45 & 100 & - & - \\
\hline
\end{tabular}


Çizelge 9. İşletme sahiplerinin işletmelerinde karşılaştıkları sorunların çözümünde iletişim kurdukları kurum ve kuruluşlar Sorunların Çözümünde İletişime Geçilen Kurum ve Kuruluşlar

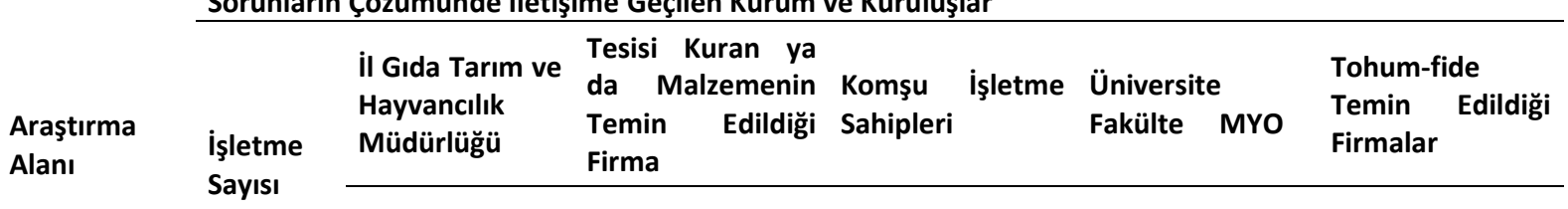

\begin{tabular}{llllllllllll} 
& & Sayı & $\%$ & Sayı & $\%$ & Sayı & $\%$ & Sayı & $\%$ & Sayı & $\%$ \\
\hline Merkez & 10 & 4 & 40 & 1 & 10 & 4 & 40 & - & - & 1 & 10 \\
İncirliova & 11 & - & - & 4 & 36.4 & 5 & 45.5 & 2 & 18.1 & - & - \\
Germencik & 5 & 1 & 20 & 4 & 80 & - & - & - & - & - & - \\
Köşk & 1 & - & - & 1 & 100 & - & - & - & - & - & - \\
TOPLAM & 27 & 5 & 18.5 & 10 & 37.1 & 9 & 33.3 & 2 & 7.4 & 1 & 3.7 \\
\hline
\end{tabular}

açısından karşılaşılan sorunların çözümünde teknik ve bilimsel yönden donanımlı kurum ve kuruluşlarla iletişimin artırılması gerekmektedir.

\section{TEŞEKKÜR}

$\mathrm{Bu}$ çalışmanın yürütülmesinde, Aydın Adnan Menderes Üniversitesi Bilimsel Araştırma Projeleri (BAP) birimi (ZRF17003 nolu proje) tarafından verilen destek için teşekkür ederiz.

\section{KAYNAKLAR}

Anonim (2015) TR63 Bölgesi, Seracılık (Örtüaltı Bitki Yetiştiriciliği) Sektör Raporu 2015 Doğu Akdeniz Kalkınma Ajansı Yayınları

Anonim (2016) Orman ve Su İşleri Bakanlığı Meteoroloji Müdürlüğü Kayıtları, Aydın.

Anonim (2017) 2. Ulusal Seracılık Çalıştayı, GIDA, TARIM VE HAYVANCILIK BAKANLIĞI BITKISEL ÜRETIM GENEL MÜDÜRLÜĞÜ, Ankara.

Anonim (2018) T.C. Tarım ve Orman Bakanlığı, Aydın II Müdürlüğü, Aydın Tarım Master Planı. Erişim Linki: https://aydin.tarimorman.gov.tr/Belgeler/Ayd\%C4\%B 1n\%20Tar\%C4\%B1m\%20Master\%20Plan\%C4\%B1/MA STER\%20PLAN\%20\%20\%2816.01.2019\%29-

converted.pdf (Erişim Tarihi: 01.02.2019)

Büyüktaş K, Atılgan A, Tezcan A (2016) Tarımsal Üretim Yapıları. Süleyman Demirel Üniversitesi, Ziraat Fakültesi Yayın No:101, Isparta.

Çanakçı M, Akıncı i (2007) Antalya İli Seralarında Kullanılan Havalandırma ve Isıtma Sistemleri. Akdeniz Üniversitesi Ziraat Fakültesi Dergisi 20(2): 241-252.

Çiçek A, Erkan O (1996) Tarım Ekonomisinde Araştırma ve Örnekleme Yöntemleri. Gaziosmanpaşa Üniversitesi, Ziraat Fakültesi Yayınları No: 12, Ders Notları Serisi No: 6, Tokat.

Eltez S, Eltez RZ (2005) Bergama ve Dikili İlçeleri (İzmir) Sera Potansiyeli ve Seracılık Faaliyetleri Üzerine Bir Araştırma. Ege Üniversitesi Ziraat Fakültesi Dergisi 42(2): 203-214.

Emekli NY, Baştuğ R, Büyüktaş T (2007) Antalya İli Kumluca İlçesindeki Seraların Mevcut Durumu, Sorunları ve Uygun Çözüm Önerilerinin Geliştirilmesi. Akdeniz Üniversitesi Ziraat Fakültesi Dergisi 20(2): 273-288.
Gale U, Tüzel Y, Öztekin GB (2014). Antalya'nın Kepez İlçesinde Geleneksel Sera Üretiminin Özellikleri. Türkiye Tarımsal Araştırmalar Dergisi 1: 68-77.

Güllüler F (2007) Adana İli ve İlçelerindeki Seraların Yapısal Özelliklerinin İncelenmesi ve T.S.E Standartlarına Uygunluğunun Araştırılması. Yüksek Lisans Tezi, Çukurova Üniversitesi Fen Bilimleri Enstitüsü, Adana.

Gökçimen H (2009) Menderes İlçesinde Hıyar Yetiştiren Sera İşletmelerinin Genel Özellikleri. Yüksek Lisans Tezi, Ege Üniversitesi Fen Bilimleri Enstitüsü, İzmir.

İşbecer ÖB (2010) Antalya İlinde Sera Sebzeciliğinin Mevcut Durumu, Sorunları ve Çözüm Önerileri. Yüksek Lisans Tezi, Süleyman Demirel Üniversitesi Fen Bilimleri Enstitüsü, Isparta.

Mercan Y (2013) Manisa Yöresinde Örtüaltı İşletmelerinin ve Üretim Sistemlerinin Yapısal Analizi ve Geliştirilmesi. Yüksek Lisans Tezi, Ege Üniversitesi Fen Bilimleri Enstitüsü, İzmir.

Şahin G, Kendirli B (2012) Türkiye'de Örtüaltı Meyve Yetiştiriciliği. Akdeniz Üniversitesi Ziraat Fakültesi Dergisi 25(1): 9-15.

Taşlıgil N, Şahin G (2014) Ziraat Coğrafyası Açısından Marmara Bölgesi'nde Örtüaltı Yetiştiriciliği. Marmara Sosyal Araştırmalar Dergisi 6:1-17.

Türkay C, Öztürk HH, Pınar H, Hocagil MM (2006) Anamur Yöresindeki Muz Seralarının Yapısal ve İşlevsel Özellikleri. Alatarım Dergisi 5(2):17-22.

Tüzel Y, Gül A, Daşgan HY, Özgür M, Özçelik N, Boyacı HF, Ersoy A (2005) Örtüaltı Yetiştiriciliğinde Gelişmeler. Türkiye Ziraat Mühendisleri VI. Teknik Kongresi Bildirileri, Ankara, 609-627.

Tüzel Y, Öztekin GB, Gül A (2008) Recent developments in protected cultivation in Turkey. 2nd Coordinating Meeting of the Regional FAO Working Group on Greenhouse Crop Production in the SEE Countries. (711 April), pp. 75-86, Antalya.

Tüzel Y, Öztekin GB, Karaman i (2010) Serik İlçesindeki Modern ve Geleneksel Sera İşletmelerinin Üretici Özellikleri, Sera Yapısı ve Sebze Üretim Teknikleri Bakımından Karşılaştırılması. Ege Üniversitesi Ziraat Fakültesi Dergisi 47(3):223-230. 
Üstün S, Baytorun AN (2003) Sera Projelerinin Hazırlanmasına Yönelik Bir Uzman Sistemin Oluşturulması. KSÜ Fen ve Mühendislik Dergisi 6 (1): 168-176.

Yalçın M, Boz i (2007) Kumluca ilçesinde Seralarda Üreticilerin Kullandıkları Bilgi Kaynakları. Bahçe Dergisi 36(1-2):1-10.
Yaslıoğlu E, Durmuş S (2017) Bursa İlinde Yetiştiricilik Yapılan Seraların Yapısal Yönden Değerlendirilmesi. Gaziosmanpaşa Üniversitesi Ziraat Fakültesi Dergisi 34 (Ek Sayı):164-171. 
